\title{
Profil Pengetahuan Siswa Sekolah Dasar Terhadap Aksara Lokal Satera Jontal (Studi Deskriptif Di SDN Lampok Sumbawa Barat)
}

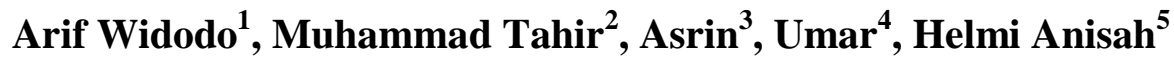 \\ Program Studi Pendidikan Guru Sekolah Dasar Universitas Mataram ${ }^{1,2,3,4,5}$ \\ arifwidodo@unram.ac.id ${ }^{1}$, sasakrengganis@gmail.com ${ }^{2}$, bajangasrin@gmail.com ${ }^{3}$, \\ umarelmubaraq@unram.ac.id ${ }^{4}$, helmianisa0@gmail.com ${ }^{5}$
}

\begin{abstract}
Abstrak
Aksara Satera Jontal merupakan salah satu aksara lokal yang dimiliki bangsa Indonesia. Keberadaan aksara lokal semakin hari semakin terkikis dengan kehadiran huruf latin. Aksara Satera Jontal sebagai bagian dari kebudayaan masyarakat Samawa mengalami nasib yang tidak jauh berbeda dengan aksara lokal lain di Nusantara. Terdapat pergeseran fungsi dan kegunaan aksara lokal. Terlebih lagi bagi pelajar generasi millenial. Tidak banyak pelajar yang memiliki pengetahuan terkait aksara lokal. Penelitian ini bertujuan untuk mendeskripsikan profil pengetahuan siswa sekolah dasar terhadap aksara Satera Jontal. Lokasi penelitian di SDN Lampok Sumbawa Barat. Subjek penelitian siswa SD kelas VI. Jumlah responden penelitian sebanyak 17 siswa. Penelitian ini didesain dalam bentuk penelitian survei dengan pendekatan deskriptif. Pengumpulan data menggunakan angket. Instrumen yang digunakan berupa angket responden. Analisis data menggunakan statistik deskriptif. Data disajikan dalam bentuk diagram. Masalah yang dikaji dalam penelitian ini adalah bagaimana tingkat pengetahuan siswa di SDN Lampok terhadap aksara Satera Jontal. Hasil penelitian menunjukkan bahwa pengetahuan siswa SD terkait aksara lokal sangat rendah. Hal ini dapat terlihat dari rendahnya kemampuan siswa dalam membaca, menulis, menyebutkan, mengenali, dan melafalkan aksara Satera Jontal.
\end{abstract}

Kata kunci: aksara lokal, satera jontal, sekolah dasar 


\section{PENDAHULUAN}

Aksara lokal merupakan kekayaan budaya bangsa yang bernilai luhur. Pengetahuan tentang aksara merupakan salah satu indikator tingginya tingkat peradaban yang pernah dicapai suatu bangsa pada masa lalu (Aranta, Bimantoro, \& Putrawan, 2020). Maka dari itu keberadaan aksara lokal harus dilestarikan. Namun demikian eksistensi aksara lokal di tengah arus modernisasi tengah mendapatkan tantangan yang berat. Krisis pengetahuan terhadap aksara lokal semakin terlihat jelas. Aksara lokal diberbagai daerah di Indonesia semakin ditinggalkan oleh masyarakat pendukungnya (Utari, Wijaya, \& Bimantoro, 2019). Terdapat beberapa faktor yang menjadi penyebab aksara lokal semakin ditinggalkan. Salah satu diantaranya adalah aksara lokal dianggap sulit untuk dipelajari bagi kalangan pelajar (Widodo, Indraswati, Novitasari, Nursaptini, \& Rahmatih, 2020). Kondisi semacam ini membuat sebagian besar pelajar enggan untuk mempelajari aksara lokal. Terlebih lagi dengan kegunaan praktis aksara lokal yang semakin tidak jelas membuat motivasi belajar generasi muda semakin pudar.

Aksara merupakan salah satu bagian dari ragam bahasa. Aksara merupakan simbol dari bahasa tulis (Aranta, Gunadi, \& Indrawan, 2018). Aksara sebagai bentuk viualisasi bahasa (Yulianti, Wijaya, \& Bimantoro, 2019). Aksara lokal pada umumnya ditulis pada daun lontar (Austin, 2014). Namun seiring dengan perkembangan zaman aksara lokal juga telah ditulis pada kertas. Seperti halnya bahasa lisan, aksara juga mengalami pergerseran (Wilian \& Husaini, 2019). Salah satu bentuk pergeseran ragam bahasa tulis adalah pergeseran fungsi. Pada awalnya aksara berfungsi sebagai alat komunikasi yaitu alat yang digunakan untuk menyampaikan pesan secara tertulis. Seiring dengan perkembangan zaman fungsi aksara lokal sebagai alat komunikasi kini telah bergeser. Menurut berbagai penelitian aksara lokal kini hanya digunakan sebagai hiasan, simbol kota dan nama jalan (Erika, 2018). Geliat penggunaan aksara lokal sebagai nama jalan sering dijumpai pada kotakota besar di Indonesia.

Pergeseran fungsi aksara lokal diberbagai daerah terdapat dampak positif dan dampak negatifnya. Dampak positifnya adalah penggunaan aksara lokal sebagai jalan dapat menjadi media kampanye pelestarian aksara lokal yang efektif. Namun demikian kampanye positif dengan penggunaan aksara lokal sebagai nama jalan 
berbanding terbalik dengan realita yang ada dalam dunia pendidikan. Masih dapat dijumpai berbagai sekolah yang tidak mengajarkan aksara lokal kepada peserta didik. Implikasinya adalah semakin banyak pelajar yang mengalami buta aksara lokal. Hal ini sungguh ironis mengingat peninggalan sejarah seperti serat dan babad banyak tertulis dalam aksara lokal. Akibatnya adalah serat dan babad sejarah yang tertulis dalam aksara lokal tidak dapat dipahami oleh para generasi muda (Hamid, 2013). Padahal serat dan babad yang merupakan peninggalan sejarah tersebut banyak mengandung nilai-nilai karakter sebagai teladan yang penuh edukasi kepada para generasi penerus bangsa.

Krisis terhadap aksara lokal juga terjadi di masyarakat Sumbawa. Aksara lokal yang digunakan oleh suku Samawa (Suku asli Pulau Sumbawa) diberi nama aksara Satera Jontal (Maulana, 2020). Menurut salah satu penelitian aksara Satera Jontal banyak mendapat pengaruh dari aksara Lontara yang dimiliki masyarakat Bugis (Ahmad, 2014). Hal ini dapat dipahami bahwa hubungan dangan kedua daerah tersebut berlangsung cukup lama, sehingga berpotensi menimbulkan akulturasi budaya. Salah satu bentuknya diwujudkan dalam bentuk aksara. Berdasarkan catatan sejarah aksara Satera Jontal merupakan salah satu aksara yang telah dikenal masyarakat Samawa sebelum kehadiran huruf latin yang dibawa oleh bangsa Portugis (Raden, 2019).

Keberadaan aksara Satera Jontal dewasa ini juga mengalami permasalahan yang serius. Dalam sebuah penelitian disebutkan bahwa aksara ini telah terancam punah (Marliana \& Jazadi, 2020). Indikasi adanya ancaman kepunahan terhadap aksara Satera Jontal adalah semakin sedikitnya penggunaan aksara dalam kehidupan sehari-hari. Selain itu minat para pelajar dalam mempelajari aksara Satera Jontal juga sangat rendah. Berdasarkan beberapa permasalahan tersebut perlu dilakukan penelitian terkait dengan profil pengetahuan siswa sekolah dasar terhadap aksara Satera Jontal. Penelitian ini penting dilakukan mengingat siswa sekolah dasar merupakan benteng utama dalam pelestarian aksara lokal di masa depan.

Terdapat beberapa penelitian terdahulu yang mengkaji tentang aksara lokal. Penelitian pertama mengkaji tentang minat belajar mahasiswa terhadap aksara Sasambo (Widodo, Umar, Sutisna, \& Tahir, 2020). Hasil penelitian tersebut menunjukkan bahwa minat belajar mahasiswa terhadap aksara lokal Sasambo sangat 
rendah. Penelitian kedua mengkaji tentang penggunaan multi media interaktif untuk meningkatkan kemampuan membaca aksara lokal (Al Masjid \& Arief, 2016). Hasil penelitiannya menyatakan bahwa multi media sangat bermanfaat untuk meningkatkan kemampuan membaca siswa pada pembelajaran aksara lokal. Penelitian ketiga mengkaji tentang pengetahuan calon guru SD terhadap aksara lokal Sasambo (Widodo, 2020). Hasil penelitiannya menunjukkan bahwa sebagian besar calon guru SD tidak memiliki kemampuan yang baik terhadap aksara lokal masingmasing. Hal ini dapat terlihat dari rendahnya kemampuan calon guru SD dalam membaca maupun menulis aksara lokal di daerahnya masing-masing.

Penelitian ini bertujuan untuk mengetahui tingkat pengetahuan siswa sekolah dasar terhadap aksara lokal Satera Jontal. Masalah yang akan dikaji adalah bagaimana kemampuan siswa dalam membaca, menulis, mengenali, menyebutkan dan menyalin aksara Satera Jontal. Melalui penelitian ini diharapkan dapat memperoleh data tentang pengetahuan siswa terhadap aksara Satera Jontal. Data dalam penelitian ini diharapkan dapat menjadi landasan dalam penelitian selanjutnya. Selain itu data penelitian ini diharpkan dapat menjadi landasan dalam mengambil kebijakan bagi para pemangku kebijakan yang terkait dengan pelestarian aksara lokal.

\section{METODE PENELITIAN}

Penelitian ini didesain dalam bentuk penelitian survei. Pendekatan yang digunakan adalah deskriptif. Penelitian dilakukan dalam kondisi alamiah tanpa perlakuan apapun terhadap responden penelitian (Nazir, 2014). Lokasi penelitian di SDN Lampok Sumbawa Barat. Jumlah responden sebanyak 17 siswa kelas VI. Pengumpulan data menggunakan angket. Instrumen utama yang digunakan berupa angket responden. Data pendukung diperoleh melalui wawancara. Informan pendukung dalam penelitian ini adalah guru di SDN Lampok. Analisis data menggunakan statistik deskriptif. Tahapan analisis data adalah pengumpulan data, tabulasi data, penyajian data dan penarikan kesimpulan. Data disajikan dalam bentuk diagram. Berikut ini disajikan indikator dalam penyusunan angke respnden. 
Tabel 1. Panduan angket responden

\begin{tabular}{cc}
\hline No & Pertanyaan \\
\hline 1 & Apakah saudara dapat mengenali bentuk aksara Satera Jontal? \\
\hline 2 & Apakah saudara dapat menyebutkan nama-nama aksara dalam aksara lokal? \\
\hline 3 & Apakah saudara dapat melafalkan aksara Satera Jontal? \\
\hline 4 & Apakah saudara dapat menyalin aksara Satera Jontal? \\
\hline 5 & Apakah saudara dapat membaca aksara Satera Jontal? \\
\hline 6 & Apakah saudara dapat menulis dalam aksara Satera Jontal?
\end{tabular}

\section{HASIL DAN PEMBAHASAN}

Penelitian ini dilakukan di SDN Lampok Sumbawa Barat. Terdapat enam pertanyaan yang diberikan kepada responden. Pertanyaan pertama berkaitan dengan kemampuan siswa dalam mengenali aksara Satera Jontal. Indikator yang digunakan dalam aspek kemampuan mengenali bentuk aksara Satera Jontal adalah siswa dapat membedakan bentuk aksara Satera Jontal dengan jenis aksara yang lain. Berdasarkan hasil survei dapat diketahui bahwa sebagian besar siswa di SDN Lampok tidak dapat mengenali bentuk aksara Satera Jontal. Berikut dapat disajikan hasil survei terhadap kemampuan siswa dalam mengidentifikasi bentuk aksara Satera Jontal.

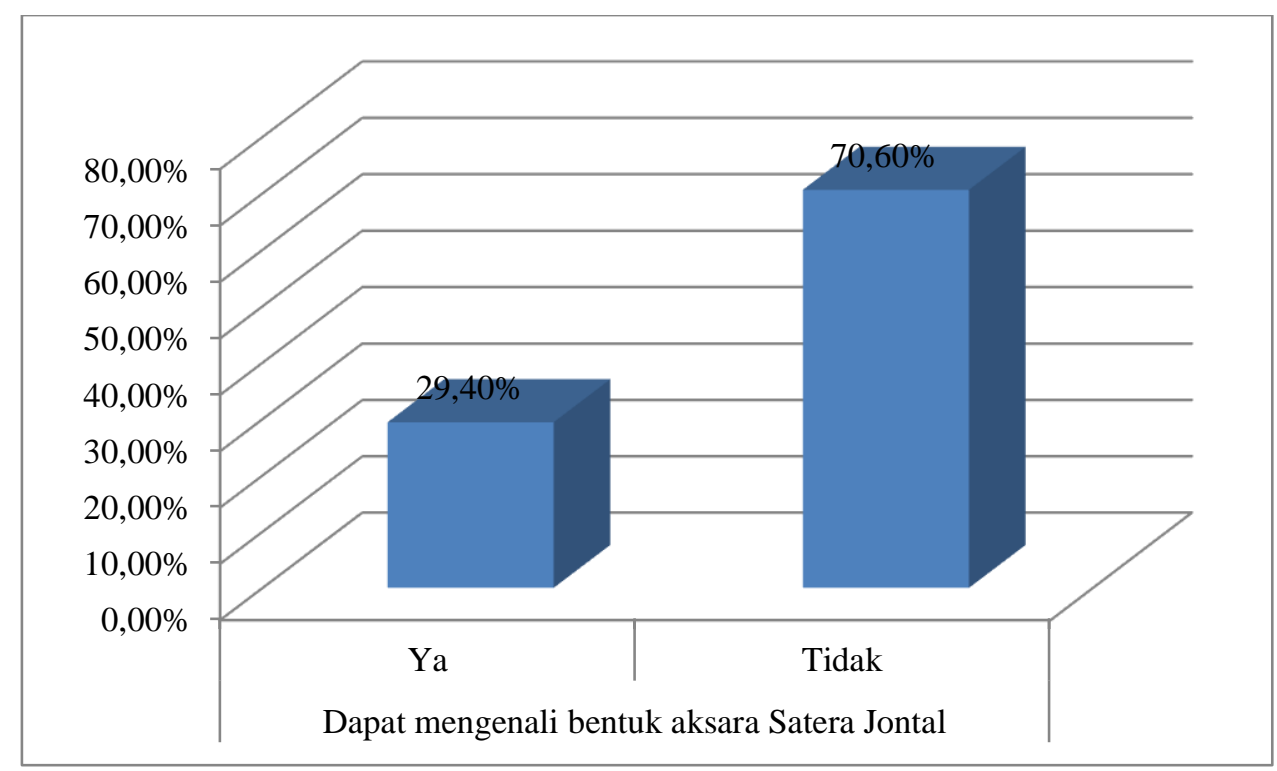

Gambar 1. Profil kemampuan siswa dalam mengenali aksara Satera Jontal

Berdasarkan pada gambar 1dapat diketahui bahwa jumlah siswa yang dapat mengenali bentuk aksara Satera Jontal hanya 29,40\%. Sebanyak 70,60\% dari siswa 
mengaku tidak dapat mengenali bentuk aksara Satera Jontal lagi. Data di atas menunjukkan bahwa hanya sedikit sekali siswa yang mampu mengenali aksara Satera Jontal sebagai aksara lokal suku Samawa.

Pertanyaan kedua berkaitan dengan kemampuan siswa dalam menyebutkan bentuk huruf aksara Satera Jontal. Sedikit berbeda dengan pertanyaan pertama, pertanyaan kedua berkaitan dengan kemampuan siswa dalam menyebutkan namanama aksara di dalam aksara Satera Jontal. Berikut ini dapat disajikan kemampuan siswa dalam menyebutkan bentuk aksara Satera Jontal.

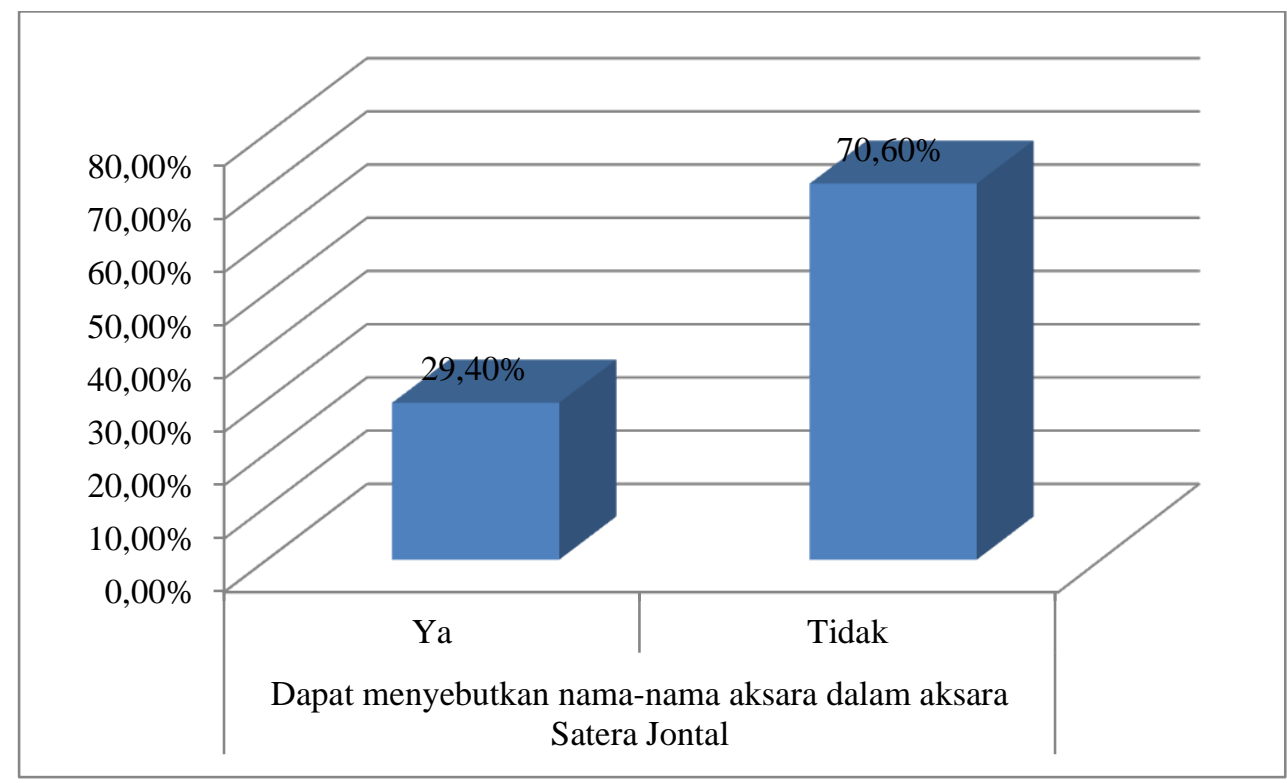

Gambar 2. Profil kemampuan siswa dalam menyebutkan nama-nama aksara dalam aksara Satera Jontal

Berdasarkan gambar 2 dapat diketahui bahwa kemampuan siswa dalam menyebutkan bentuk aksara Satera Jontal tergolong rendah. Jumlah siswa yang mengaku dapat menyebutkan nama-nama aksara dalam aksara Satera Jontal hanya $29,40 \%$, sedangkan sisanya sebanyak $70,60 \%$ mengaku tidak dapat menyebutkan nama-nama aksara dalam aksara Satera Jontal. Hasil survei pada aspek kedua tidak jauh berbeda dengan hasil survei pada aspek pertama. Hal ini menunjukkan bahwa kedua aspek ini saling berkaitan. Kemampuan dalam menyebutkan nama-nama aksara berbanding lurus dengan kemampuan siswa dalam mengenali bentuk aksara Satera Jontal. 


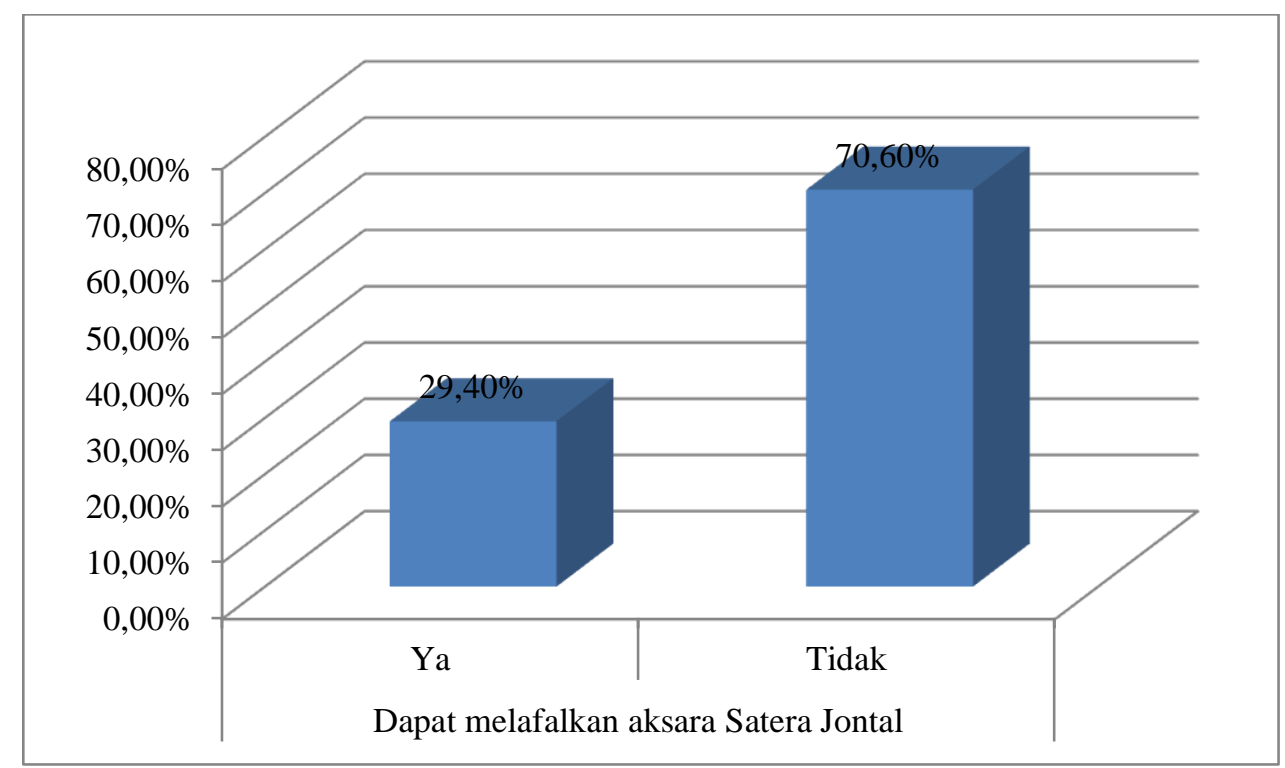

Gambar 3. Profil kemampuan siswa dalam melafalkan aksara Satera Jontal

Aspek ketiga yang dipertanyakan kepada siswa berkaitan dengan kemampuan siswa dalam melafalkan aksara Satera Jontal. Berdasarkan gambar 3 dapat dipahami bahwa aspek ketiga yang dipertanyakan kepada siswa menghasilkan data yang tidak berbeda dengan dua aspek sebelumnya. Hal ini menunjukkan bahwa ketiga aspek ini saling berkaitan. Siswa tidak dapat melafalkan aksara lokal jika sebelumnya tidak mampu mengenali bentuk aksara dan tidak mampu menyebutkan nama-nama aksara dalam aksara Satera Jontal.

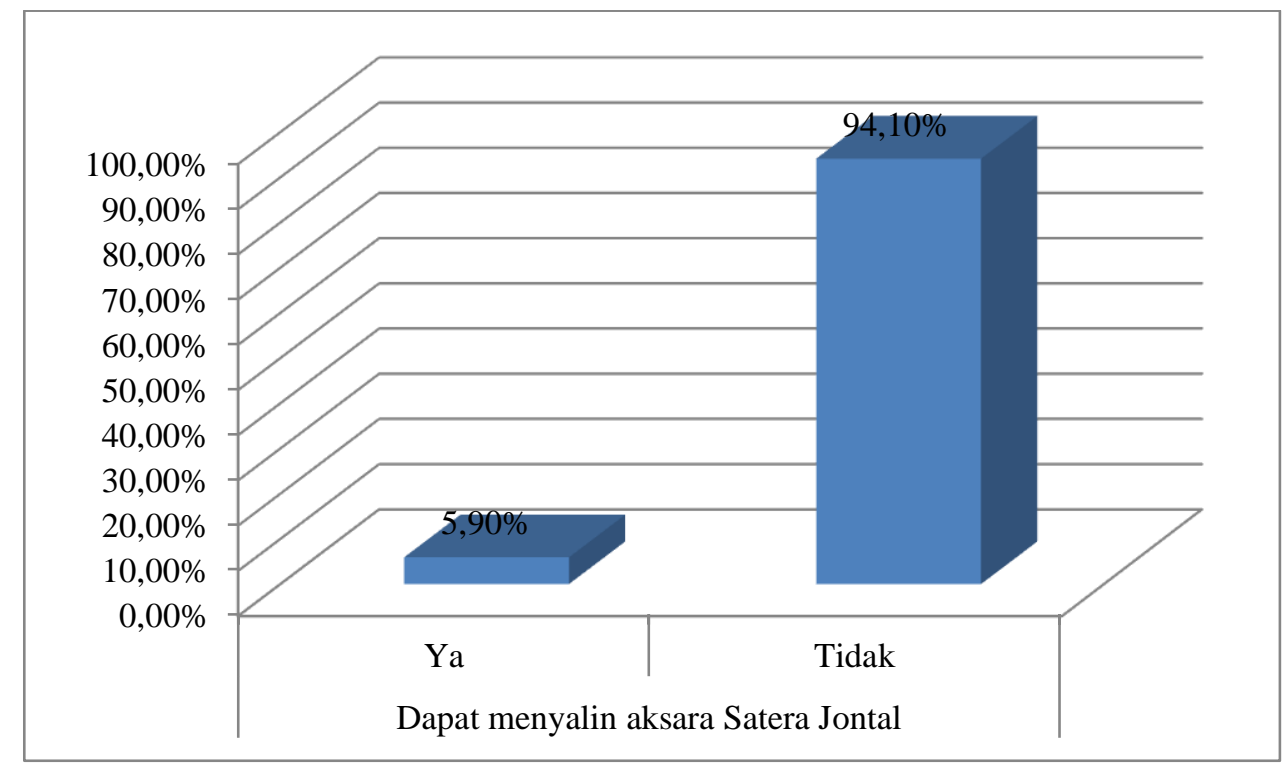

Gambar 4. Profil kemampuan siswa dalam menyalin aksara Satera Jontal

Pertanyaan keempat berkaitan dengan kemampuan siswa dalam menyalin aksara Satera Jontal. Indikator yang digunakan untuk mengetahui kemampuan siswa 
dalam menyalin adalah siswa dapat melakukan duplikasi terhadap aksara Satera Jontal. Berdasarkan gambar 4 dapat diketahui bahwa siswa yang dapat menyalin aksara Satera Jontal dengan tulisan tangan sebanyak hanya 5,90\% dari 17 responden. Sisanya sebanyak 94,10\% tidak dapat menyalin aksara tersebut. Data ini menunjukkan bahwa kemampuan siswa dalam menyalin aksara Satera Jontal sangat rendah.

Aspek kelima yang ditanyakan adalah kemampuan siswa dalam membaca teks aksara Satera Jontal. Berikut dapat disajikan hasil survei terhadap kemampuan siswa dalam membaca aksara Satera Jontal

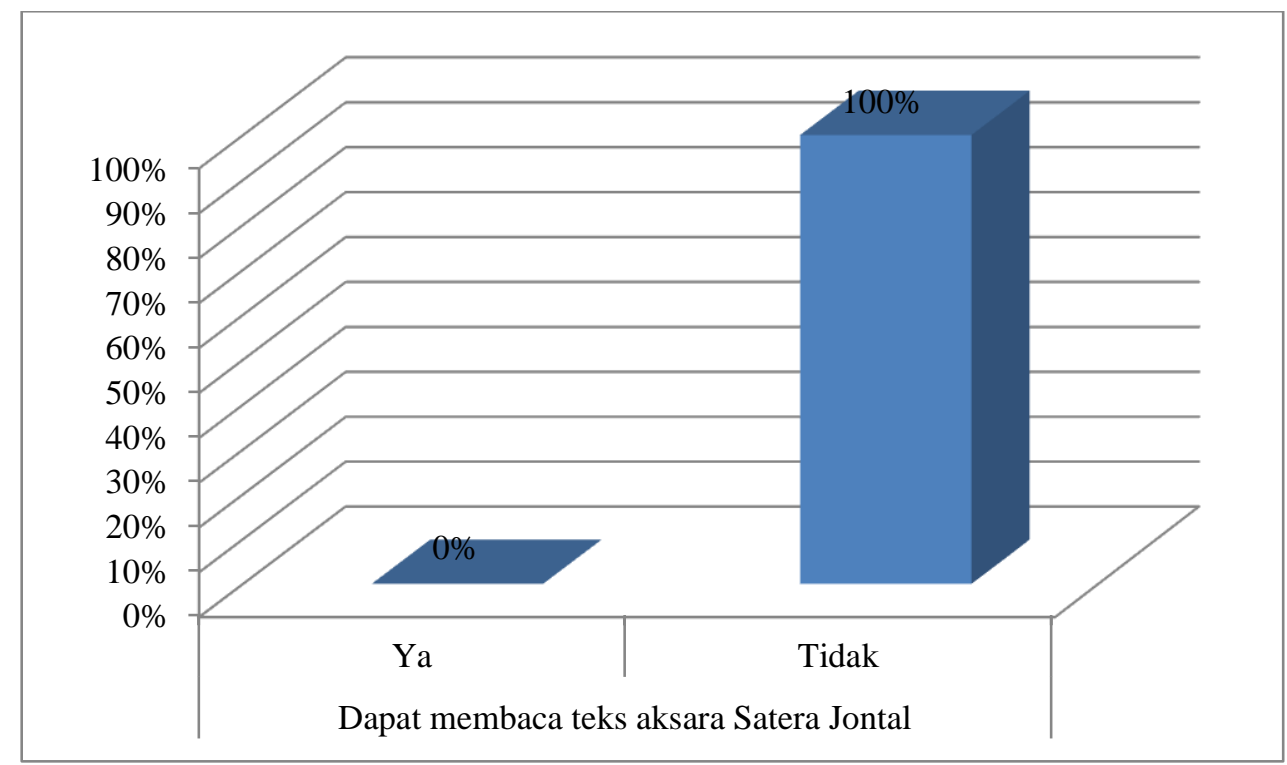

Gambar 5. Profil kemampuan siswa dalam membaca teks aksara Satera Jontal

Berdasarkan data di atas didapatkan data yang sungguh mengejutkan. Dari 17 siswa yang dilakukan survei tidak ada satupun siswa yang dapat membaca teks aksara Satera Jontal. Hal ini menunjukkan bahwa semua siswa tidak mempunyai kemampuan dalam membaca aksara Satera Jontal. Hasil survei terhadap kemampuan membaca tidak berbeda dengan kemampuan menulis aksara. Pada aspek penulisan ditemukan fakta bahwa tidak ada satupun siswa yang mampu menulis aksara Satera Jontal. Berikut dapat disajikan hasil survei terhadap kemampuan menulis aksara Satera Jontal. 


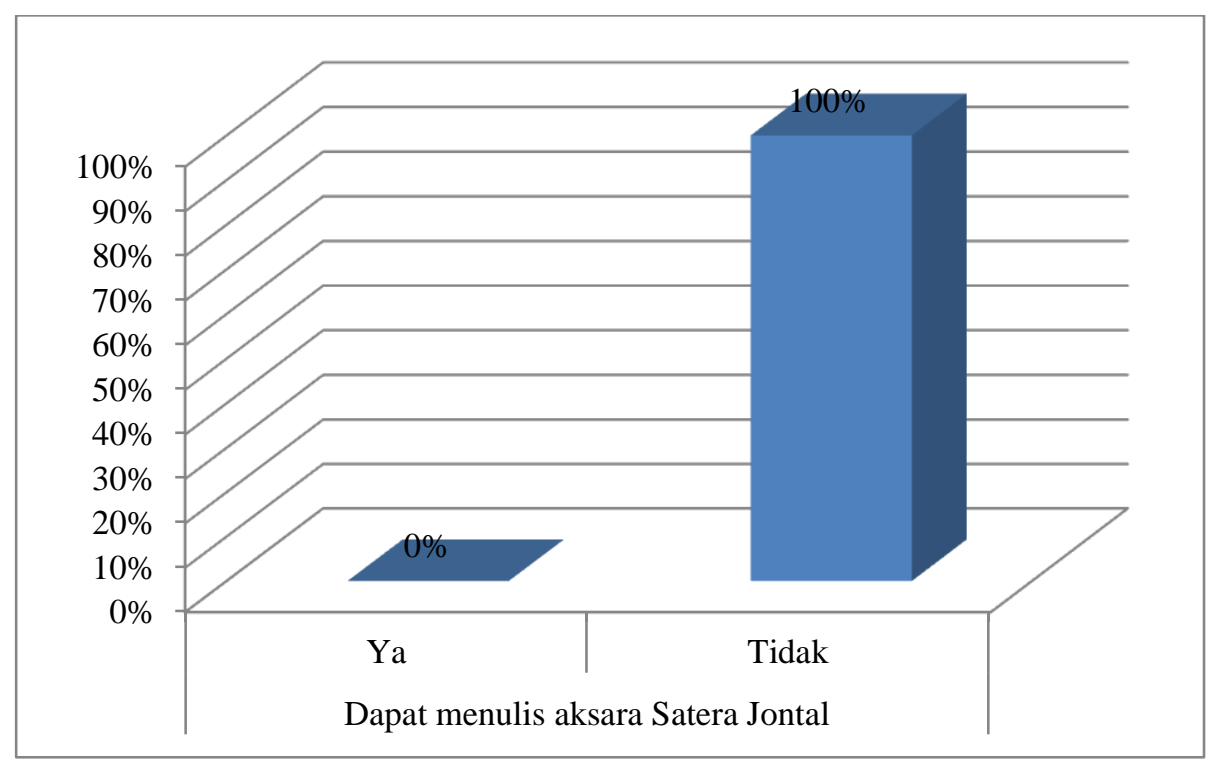

Gambar 6. Profil kemampuan siswa dalam menulis aksara Satera Jontal

Berdasarkan gambar 6 dapat diketahui bahwa semua siswa yang dilakukan survei tidak memiliki kemampuan dalam menulis aksara Satera Jontal. Pada aspek keenam dan aspek keempat walaupun keduanya berkaitan dengan aspek penulisan tetapi memiliki perbedaan terkait dengan indikator yang harus dicapai. Pada aspek menyalin siswa hanya melakukan duplikasi dengan tulisan tangan terhadap aksara Satera Jontal yang sudah ada, sedangkan pada aspek menulis aksara siswa mengubah redaksi dari huruf latin ke aksara Satera Jontal. Hasil survei seperti terlihat pada gambar 6 yang menunjukkan tidak ada satupun siswa yang dapat menulis aksara Satera Jontal.

Rendahnya hasil survei terhadap pengetahuan siswa terhadap aksara Satera Jontal kemudian dilakukan konfirmasi kepada beberapa guru kelas di SDN. Hasil wawancara menunjukkan bahwa pelajaran aksara Satera Jontal selama ini memang tidak diajarkan di sekolah. Salah satu penyebabnya adalah kurangnya sumber daya manusia yang menguasai aksara Satera Jontal. Hal inilah yang menjadi salah satu penyebab rendahnya pengetahuan siswa terhadap aksara Satera Jontal. Sebagian siswa yang dapat mengenali aksara Satera Jontal karena diajari orang tua masingmasing. Hal ini perlu mendapat perhatian mengingat ujung tombak pelestarian aksara lokal adalah siswa sekolah dasar.

Pemangku kebijakan dan instansi terkait perlu memikirkan langkah-langkah konkrit agar krisis terhadap aksara lokal dapat diatasi. Evaluasi terhadap pelaksanaan pembelajaran di sekolah perlu dilakukan secara berkala (Alwi \& Sholihat, 2019). 
Terlebih lagi yang berkaitan berkaitan dengan pembelajaran aksara Satera Jontal harus dilakukan evaluasi dalam tataran kebijakan maupun implementasi dalam pembelajaran. perlu adanya kerjasama dari berbagai pihak agar keterlaksanaan kegiatan pembelajaran aksara dapat berjalan dengan lancar (Nursaptini et al., 2020).

Pembelajaran aksara termasuk juga dalam pembelajaran literasi. Hal ini dikarenakan membaca dan menulis merupakan salah satu dari keterampilan berbahasa (Siregar \& Yunitasari, 2019). Perbedaannya hanya terletak pada cakupan bahasa yang digunakan. Kearifan lokal memiliki kontribusi yang besar dalam menuntun perilaku peserta didik. Kearifan lokal memberikan memiliki nilai-nilai edukasi dalam berperilaku yang bijak, toleransi serta sikap kesederhanaan (Widodo, Maulyda, et al., 2020). Siswa perlu diberi bekal sebagai antisipasi terhadap perubahan zaman (Sutisna et al., 2020). Terlebih lagi telah terdapat banyak media lokal yang dapat digunakan sebagai bahan literasi berbasis kearifan lokal (Suhendra \& Wulansari, 2018). guru dituntut untuk kreatif dan inovatif dalam mengembangkan pembelajaran aksara lokal. Maka dari itu pendidikan berbasis kearifan lokal masih dapat dilakukan asalkan masih ada komitmen bersama untuk menyelamatkan aksara warisan leluhur bangsa.

\section{SIMPULAN}

Berdasarkan hasil penelitian dan pembahasan dapat diketahui bahwa tingkat pengetahuan siswa sekolah dasar di SDN Lampok Barat sangat rendah. Hal ini dapat terlihat dari beberapa indikator antara lain: Jumlah siswa yang dapat mengenali, menyebutkan nama-nama aksara dan mampu melafalkan aksara lokal Satera Jontal hanya sebesar 29,40\%. Jumlah siswa yang dapat menyalin aksara Satera Jontal hanya sebesar 5,90\%. Indikator terakhir adalah tidak ada satupun siswa yang dapat membaca dan menulis aksara Satera Jontal. Dari beberapa indikator yang telah disebutkan menunjukkan bahwa tingkat pengetahuan siswa sekolah dasar terhadap aksara Satera Jontal masih sangat rendah. 


\section{DAFTAR PUSTAKA}

Ahmad, A. A. (2014). Melestarikan Budaya Tulis Nusantara: Kajian Tentang Aksara Lontara. Jurnal Budaya Nusantara, 1(2), 148-153.

Al Masjid, A., \& Arief, A. (2016). Penggunaan Multimedia Interaktif untuk Meningkatkan Kemampuan Membaca Aksara Jawa Pada Siswa Kelas 5 SD Negeri Blimbing 4. Pendidikan Ke-SD-An, 3(1), 48-54.

Alwi, M., \& Sholihat, Z. (2019). Pengembangan Instrumen Evaluasi Pembelajaran Pada Karya Sastra Berbasis Budaya Lokal Kelas IV MI NW Tebaban. Jurnal DIDIKA: Wahana Ilmiah Pendidikan Dasar, 5(1), 40-47. https://doi.org/10.29408/didika.v5i1.1778

Aranta, A., Bimantoro, F., \& Putrawan, I. P. T. (2020). Penerapan Algoritma Rule Base dengan Pendekatan Hexadesimal pada Transliterasi Aksara Bima Menjadi Huruf Latin. Jurnal Teknologi Informasi, Komputer, Dan Aplikasinya (JTIKA ), 2(1), 130-141. https://doi.org/10.29303/jtika.v2i1.96

Aranta, A., Gunadi, Ig. A., \& Indrawan, G. (2018). Utilization Of Hexadecimal Numbers In Optimization Of Balinese Transliteration String Replacement Method. 2018 International Conference on Computer Engineering, Network and Intelligent Multimedia (CENIM), 131-136. https://doi.org/10.1109/CENIM.2018.8711118

Austin, P. K. (2014). Aksara Sasak, an endangered script and scribal practice. Proceedings of the International Workshop on Endangered Scripts of Island Southeast Asia, (February), 1-12. Retrieved from https://docplayer.net/39228817-Aksara-sasak-an-endangered-script-and-scribal-practice.html

Erika, F. (2018). Geliat Aksara dan Bahasa Ganda dalam Papan Nama Jalan di Indonesia. Seminar Dan Lokakarya Pengutamaan Bahasa Negara, 226-238. Retrieved from https://www.researchgate.net/profile/Fajar_Erikha/publication/330512699 Hamid, S. A. (2013). Translation of Manuscripts in Lombok: an Effort To Understand the Sasak' S Cultural Values. MABASAN, 7(2), 75-84. Retrieved from http://download.garuda.ristekdikti.go.id/article.php?article=

Marliana, E., \& Jazadi, I. (2020). The Need To Revive Satera Jontal An Endangered Script In Sumbawa Regency. Journal Unmasmataram, 14(2), 691-698.

Maulana, R. (2020). Aksara-aksara di Nusantara: Seri Baca Tulis: Ensiklopedia Mini, Tabel Aksara, Latihan Baca Tulis. Retrieved from https://books.google.co.id/books?id=_grfDwAAQBAJ\&dq=satera+jontal\&lr=\& $\mathrm{hl}=\mathrm{id} \&$ source $=\mathrm{gbs} \_$navlinks_s

Nazir, N. (2014). Metode Penelitian. Bogor: Ghalia Indonesia. 
Nursaptini, N., Anar, A. P., Indraswati, D., Wiododo, A., Novitasari, S., \& Sutisna, D. (2020). School Operational Assistance and Challenges of Communities' Participation at Madrasah Tsanawiyah in Central Lombok. Proceedings of the 1st Annual Conference on Education and Social Sciences (ACCESS 2019), 465(Access 2019), 279-282. https://doi.org/10.2991/assehr.k.200827.070

Raden, A. Z. M. (2019). Adaptasi Kearifan Lokal Nusantara Pada Perancangan Huruf Digital Tapis dan Gorga. Jurnal Budaya Nusantara, 2(2), 267-271.

Siregar, M. D., \& Yunitasari, D. (2019). Meningkatkan Membaca Menulis Melalui Teknik SAS Kelas 3 MI No. 1 Pancor Lombok Timur. Jurnal DIDIKA: Wahana Ilmiah Pendidikan Dasar, 5(1), 32. https://doi.org/10.29408/didika.v5i1.1788

Suhendra, R., \& Wulansari, D. (2018). Pemanfaatan Cerita Rakyat Sumbawa Sebagai Bahan Literasi Siswa Sekolah Dasar. https://doi.org/10.31227/osf.io/rp6tb

Sutisna, D., Widodo, A., Nursaptini, N., Umar, U., Sobri, M., \& Indraswati, D. (2020). An Analysis of the Use of Smartphone in Students' Interaction at Senior High School. Proceedings of the 1st Annual Conference on Education and Social Sciences (ACCESS 2019), 465(Access 2019), 221-224. https://doi.org/10.2991/assehr.k.200827.055

Utari, E. D. J., Wijaya, I. G. P. S., \& Bimantoro, F. (2019). Handwritten Sasak Ancient Script Recognition using Integral Pojection and Neural Network. Journal of Computer Science and Informatics Engineering (J-Cosine), 3(1), 19. https://doi.org/10.29303/jcosine.v3i1.222

Widodo, A. (2020). Profil Pengetahuan Calon Guru SD Terhadap Literasi Aksara Lokal Sasambo. Jurnal Pedagogik, 07(01), 74-106. Retrieved from https://ejournal.unuja.ac.id/index.php/pedagogik/article/viewFile/1085/598

Widodo, A., Indraswati, D., Novitasari, S., Nursaptini, N., \& Rahmatih, A. N. (2020). Interest of Learning Local Script Sasambo PGSD Students University Mataram. Primary: Jurnal Pendidikan Guru Sekolah Dasar, 9(3). https://doi.org/10.33578/jpfkip.v9i3.7895

Widodo, A., Maulyda, M. A., Fauzi, A., Sutisna, D., Nursaptini, N., \& Umar, U. (2020). Tolerance Education Among Religious Community Based on the Local Wisdom Values in Primary Schools. Proceedings of the 1st Annual Conference on Education and Social Sciences (ACCESS 2019), 465(Access 2019), 327330. https://doi.org/10.2991/assehr.k.200827.082

Widodo, A., Umar, U., Sutisna, D., \& Tahir, M. (2020). Primary School Teacher Prospective Perception Of Sasambo Local Script Preservation In NTB. Jurnal Pendidikan Dan Kebudayaan Missio, 12(2), 116-129. https://doi.org/10.36928/jpkm.v12i2.424 
Wilian, S., \& Husaini, B. N. (2019). Pergeseran pemakaian tingkat tutur (basa alus) bahasa sasak di Lombok. Linguistik Indonesia, 36(2), 161-185. https://doi.org/10.26499/li.v36i2.82

Yulianti, R., Wijaya, I. G. P. S., \& Bimantoro, F. (2019). Pengenalan Pola Tulisan Tangan Suku Kata Aksara Sasak Menggunakan Metode Moment Invariant dan Support Vector Machine. Journal of Computer Science and Informatics Engineering (J-Cosine), 3(2), 91-98. https://doi.org/10.29303/jcosine.v3i2.181 